\title{
THE RIGHT TO A FAIR TRIAL IN THE EU: LIGHTS AND SHADOWS
}

SUSANA GALERA 


\section{SUMMARY}

1. THE RIGHT TO A FAIR TRIAL GRANTED BY ARTICLE 47 OF THE CHARTER. 2. THE PREVIOUS DEVELOPMENTS: FROM PRINCIPLES TO INDIVIDUAL RIGHTS AND TO THE CHARTER. 3. THE EU REMEDIES. 3.1 Direct actions. a) Infringements by EU institutions and bodies, b) Infringements by Member States. 3.2 Indirect actions: preliminary references. 4. PERSISTENT GAPS ON THE EU JUDICIAL REMEDIES FROM THE RIGHT TO A FAIR TRIAL PERSPECTIVE. 4.1 Access to the ECJ for individuals. The preliminary reference as (alleged) compensation. 4.2 Judicial independence. a) National judicial functions limited by a Council Regulation? The search warrants. b) Commission v. national courts criteria: Commission pre-eminence? 5. FINAL. 


\title{
THE RIGHT TO A FAIR TRIAL IN THE EU: LIGHTS AND SHADOWS
}

\author{
SUSANA GALERA \\ Prof. Titular Derecho Administrativo \\ Universidad Rey Juan Carlos
}

\section{THE RIGHT TO A FAIR TRIAL GRANTED BY ARTICLE 47 OF THE CHARTER}

The resolution of legal disputes by an independent judicial body is a requirement stated worldwide by the Rule of Law tradition. In the event that disputes oppose private parties to public powers, such judicial remedies acquire a further role as they are a means to achieving the general submission of public powers to the Law, which is another key element required by the Rule of Law tradition. From this - public law- perspective, there is a very close link between the legality of the activity of public person and the individual rights relating to «Justice». They are the two sides of the coin which are displayed when citizens exercise their rights before the courts challenging public decisions: in seeking judicial protection of their rights, individuals keep public powers within their legal bounds and limits.

It was in 1986 that the European Court of Justice (ECJ) first referred to the legal order formed by the Community Treaties as the "constitutional charter», the central idea of this «charter» being the submission of (European) public power to judicial review as imposed by the rule-of-law tradition ${ }^{1}$. Earlier the Court had recognised the right to a fair trial as a common principle of Community law, directly connected with judicial review requirements.

ECJ 23 April 1986, Case 294/83, Les Verts. 
In 2008, the Court reiterated this doctrine: «The Community is based on the rule of law, inasmuch as neither its member states nor its institutions can avoid review of the conformity of their acts with the basic constitutional charter, the EC Treaty, which established a complete system of legal remedies and procedures designed to enable the Court of Justice to review the legality of acts of the institutions» ${ }^{2}$.

Title VI of the Charter is devoted to the rights relating to «Justice», starting with Article 47, which grants three different rights.

\section{Article 47}

\section{Right to an effective remedy and to a fair trial}

Everyone whose rights and freedoms guaranteed by the law of the Union are violated has the right to an effective remedy before a tribunal in compliance with the conditions laid down in this Article.

Everyone is entitled to a fair and public hearing within a reasonable time by an independent and impartial tribunal previously established by law. Everyone shall have the possibility of being advised, defended and represented.

Legal aid shall be made available to those who lack sufficient resources in so far as such aid is necessary to ensure effective access to justice.

These provisions have their echo in the different rights provided for in the European Convention of Human Rights (EConHR from now on), whose interpretation by the ECHR has to be taken into account in order to set the content and scope of the rights provided for by the Charter as stated in its Article 52 (Scope of Granted Rights) ${ }^{3}$. The correspondence is as follows:

- The right referred to on the first paragraph corresponds to the right to an effective remedy granted by Article 13 of the EConHR;

- The right referred to on the second paragraph corresponds to the right to a fair trial granted by Article 6(1) of the EConHR;

- The right referred to on the third paragraph corresponds to legal aid which has been recognized by the ECHR case-law as eventually being part of the right to access to the courts.

It could be thought that in countries with a large democratic tradition remedies exist for every citizen who tries to invoke a right legally provided for, and consequently that Article 13 would be intended for more recent democracies.

ECJ 3 Sep 2008, Cases C-402/05 and C-415/05 P, Al Barakaat et al.

3 See the ECJ's interpretation of article 52, third paragraph, in its Judgement of 22 December 2010, Case C-279/00. 
This is a wrong conclusion as shown by the ECHR case-law, although it is true that Article 6(1) is much more frequently invoked than Article 13.

Recently, the ECHR has ruled on some cases which illustrate the scope of the right to an effective remedy and the situations where it can be invoked... even in consolidated democracies. According to this case-law, breaches of Article 13 have been declared in the following situations:

- Different remedies are provided for with different purposes, but they work in such a way that a claim for specific rights provided by the European convention went unconsidered (UK 2012) ${ }^{4}$;

- Remedies provided for asylum procedures do not comply with the rigorous conditions required by the ECHR in such procedures, particularly with the suspension effects of judicial remedies used against a negative resolution following the asylum request (Check Republic 2011);

- Security and organizational measures on prisoners have to be admitted as being the object of a judicial remedy, rejecting the notion that such measures are just internal measures stated by Ministry of Interior which cannot be challenged (France 2009) ${ }^{6}$.

Concerning the legal aid which is referred to in the third paragraph, it is an issue which has been partially harmonized by international and European measures ${ }^{7}$ relating to natural persons. Recently ${ }^{8}$, the Court has been asked for the first time whether the mechanism for legal aid, intended to exempt persons from payment of the administrative charge for proceedings, could be excluded from application to legal persons by national law. The ECJ, after a careful exam of the ECHR case-law, does not exclude that such aid could be

4 ECHR 13.06.2012, Reynolds vs. UK, relating a claim for compensation referred to a patient's death while he was interned in a hospital belonging to the public health system.

5 ECHR 23.11.2011, Diallo vs. Czech Republic, where the Court applies its previous criteria on remedies relating asylum procedures (close and rigorous scrutiny of a claim and a remedy with automatic suspensive effect), due to the close potential connection of the asylum seek with the right of provided by article 3 ECHR (prohibiting torture and «inhuman or degrading treatment or punishment»).

6 ECHR 9.10.2009, Khider v. France, relating security measures (isolation, transfers and frisks) on prisoners on the basis of an internal Ministry of Interior's notices addressed to the penitentiary centers.

7 See the internacional and european law the General Advocate Mr. Mengozzi refers to in its conclusions ( 2 september 2010) in Case C-279/09. Relating the European law, in addition to the ECJ's Rules of Procedure, references are made to the Council Directive 2003/8/EC establishing minimum common rules relating to legal aid for cross-border disputes.

8 Case C-279/09 referred to above. 
necessary for a legal person on the basis of the principle of effective judicial protection and access to courts. Furthermore, it states the criteria which have to be taken into consideration by the national court while assessing whether the requirements for legal aid constitute a limitation on the right of access which undermines the very core of that right and the proportionality criteria is respected.

Turning to the right to a fair trial, which is the object of this work, its understanding requires a consideration of the process of recognition of such a right, the context and main EU legal fields where it comes from and, finally, the discussion of some classic and still persistent gaps in its content.

\section{THE PREVIOUS DEVELOPMENTS: PROCEDURAL GUARANTEES, PRINCIPLES, INDIVIDUAL RIGHTS AND THE CHARTER}

Initially, the objectives of the European Communities were merely economic, and the original Treaties did not include any provisions relating to the individual's legal position. However, the need for such provisions soon surfaced as, increasingly, Community activity directly involved the citizens' legal status. In the late 1960s, the Luxembourg Court gave recognition to some procedural guarantees (particular and general) to fundamental rights, including them among the General Principles of Law which fall under Community law. Later, these «principles» evolved in Luxembourg's case law into «fundamental rights» and finally Community law included specific guarantees for human rights, first in the European Single Act (1985) and later in the Maastricht (1992) and Amsterdam (1997) Treaties?.

Once the ECJ formally dismissed the possibility of the EU's accession to the European Convention because of a lack of legal basis in the Treaties ${ }^{10}$, the EU began working on its own «Bill of Rights». First, the "Charter of Fundamental Rights of the European Union» was formally «proclaimed» in Nice in 2000. Later, it was included in the so-called «Constitutional Treaty» and, finally, it was definitively given legal status by the Lisbon Treaty, which also

9 See E. BARBIER DE LA SERRE, «Procedural justice in the European Community case law concerning the rights of the defence: essentialist and instrumental trends», European Public Law, 2006, Vol. 12, No. 2, pp. 225-250 in toto.

10 These criteria are described in the ECJ's well-known Opinion 2/94. However, I join those scholars who state that these reasons were «unpersuasive» (P. Alston and J. H. H. Weiler, «An 'Ever Closer Union' in need of a Human Rights Policy: the EU and Human rights», available at www.jeanmonnetprogram.org/papers/99/990110.html). 
provides the legal basis for the EU's further accession to the European Convention.

It is important to recall that, when Community law began to consider these non-economic issues, a sort of European public order on fundamental rights and rule of law had already been developed by the Judges in Strasbourg. That explains the persistent ECJ's assertion to the European Convention and to the ECHR's criteria, whose recent and well-known judgement on the Bosphorous case clearly describes and summarises this EU process ${ }^{11}$ :

the ECJ held as early as 1969 that fundamental rights were enshrined in the general principles of Community law protected by the ECJ. By the early 1970s the ECJ had confirmed that, in protecting such rights, it was inspired by the constitutional traditions of the member states and by the guidelines supplied by international human rights treaties on which the member states had collaborated or to which they were signatories. The Convention's provisions were first explicitly referred to in 1975 and by 1979 its special significance amongst international treaties on the protection of human rights had been recognised by the ECJ. Thereafter the ECJ began to refer extensively to Convention provisions (sometimes where the EC legislation under its consideration had referred to the Convention) and latterly to this Court's jurisprudence, the more recent ECJ judgments not prefacing such Convention references with an explanation of their relevance for EC law.

The «procedural rules» stated by the ECJ first arose during implementation of the Community's Competition Law, the most important substantive Community law contribution to a codification of procedural rights at the European level (especially in the first years after its passage). Implementation of the Competition Law was, and still is, the most important administrative activity directly managed by the European Commission's services. The law's provisions tend to be applied with great severity and frequently affect individual rights. Examples include inspections in a company building without staff permission, information requirements whose answers could cause self-incrimination, and access to the Commission's files during an investigation; consequently, it has been recognized, as a general principle of EU law ${ }^{12}$, «the need for protection against arbitrary or disproportionate intervention by public authorities in the sphere of the private activities of any person».

11 Bosphorous Hava v. Ireland, European Court of Human Rights 30 Jun 2006, pt. 73. This judgment is full of ECJ case law references: I have omitted them for easier reading.

12 Case C-94/00 Roquette Frères 2002, paragraph 27 and case-law there cited), principle which later has been acknowledged as the right of privacy and family life by article 7 of the Charter, as states the ECJ pf 14 November 2012, Case T-135/09. 
In this context, the ECJ set up procedural rules on a case-by-case basis, following notwithstanding a «reluctant approach» to human rights issues ${ }^{13}$ : When human rights were involved in a case, the ECJ usually handed down a judgment that left questions about human rights unanswered. That is, ECJ decisions resolved the disputes in the end by avoiding any general criteria about the related procedural rights. The Community institutions were then much more concerned with efficient implementation of competition and other key rules for the Common Market than with the elaboration of a sort of code of procedure. In fact, the general opinion is that in the early cases the ECJ was more focused on administrative action and only later turned to the subjective rights of individuals ${ }^{14}$.

From a general scope, the pre-eminent role of the «right to justice» in developing the catalogue of fundamental rights has been pointed out ${ }^{15}$. The ECJ has repeatedly stated its protection at Community level, distinguishing the following as included in this right: the right to a fair trial, «inspired in Article 6 of the ECHR ${ }^{16}$; the right to an independent court, independent, in particular, from the executive powers ${ }^{17}$; rights of defence relating to an administrative procedure and a judicial one ${ }^{18}$; and the duty to state the reasons on which decisions are based, so as to allow the parties to defend their rights and the Court to exercise its supervisory jurisdiction ${ }^{19}$.

It should be noted that, just as it occurred with the right to a fair trial, the right of access to court has given rise to a cluster of other guarantees for individuals. While the administrative activity of community bodies has been scrutinized by the ECJ, the potential of the right to access to the

13 D. SPIELMANN, «Human rights case law in the Strasbourg and Luxembourg courts: conflicts, inconsistencies and complementarities» in P. Alston (ed.), The European Union and buman rights, Oxford, 1999, p. 766, identifies Case 136-79 National Panasonic as the most significant for this issue.

14 J. SCHWARZE, «The role of the European Court of Justice in shaping legal standards for administrative action in the member states: a comparative perspective» in D. O'Keeffe (ed.), Judicial Review in EU Law, Kluwer Law International, The Hague, 2000, at p. 450.

15 For a clear view on these developments, see C. Harlow, «Access to Justice as a human right. The European Convention and the European Union», and D. Spielmann, «Human Rights Case Law in the Strasbourg and Luxembourg Courts: conflicts, inconsistencies and complementarities», both works in The EU and Human Rights, ed. P. Alston, M. Bustelo and J. Heenan, Oxford University Press, 1999. Also, the European Court of Human Rights 30 Jun 2006, Bosphorous Hava v. Ireland, reports in paragraph 73 the Luxembourg's case law on this field.

16 ECJ 17 December 1998, C-185/95.

17 ECJ 11 January 2000, C-174/98

18 ECJ 11 July 1968, C-35/67.

19 ECJ 14 December 1990, C-350/88 
court was expanded into a set of due process principles, reflecting the classic rule-of-law preoccupations with equality before the law, the non-retrospectivity principle, an impartial and independent judge and a fair trial ${ }^{20}$. These principles, to which the Strasbourg Court has been «a non-negligible source of influence and cross-fertilisation ${ }^{21}$, have found their way into modern human rights texts; specifically, the due process rights have became a «fourth generation» of human rights in the latest text, taking the shape of «principles of good administration» ${ }^{22}$, currently granted by Article 35 of the Charter.

\section{THE EU JUDICIAL REMEDIES}

Following the 2008 ECJ's statement (the Treaty establishes a «complete system of legal remedies and procedures» for the ECJ to review (...) the conformity with the Treaties of the activities of EU institutions and Member States ${ }^{23}$, a short consideration of such remedies and procedures seems to be convenient. .

These remedies are provided for by the TFEU section devoted to the Court of Justice of the European Union, Articles 251 and following; among them, it could be distinguished between direct actions before the ECJ (mainly, action for annulment, action against unlawful omissions and action against national infringements) and indirect actions (preliminary references) which directly link the ECJ with the national judicial body which is dealing with a procedure where EU Law is to be applied.

The next paragraph will refer to these different remedies, describing in short the three more pre-eminent ones, and particularly stressing the requirements for individuals to be allowed to bring such remedies before the courts.

20 C. HARLOW, «Global administrative law: the quest for principles and values», European Journal of International Law, No. 17 (2006), p. 190, stressing a direct link: rule of law-access to court-due process.

21 STORSKRUBB and ZILLER, «Access to justice in European comparative law» in F. Francioni (ed.), Access to justice as a human right, Oxford, 2007, p. 180. Following Cappeletti's asserts, the previously underlined the process of «constitutionalisation, socialisation and internationalisation of the protection of procedural guarantees» in Europe after the Second World War.

22 C. HARLOW, «Global administrative law», op. cit.

23 See above Footnote 2. 


\subsection{Direct actions}

Within the framework of direct actions to be considered, a further distinction could be made depending on the subject who holds the defendant's position, that is, on the basis of whether it is the EU institutions or Member States that are not acting in conformity with the Treaties or with secondary EU law.

a) Infringements by EU institutions and bodies.

The action for annulment is the pre-eminent remedy allowing the ECJ to review the legality of acts adopted by the European institutions, bodies, offices or organisations. Thus, the Court shall annul the act concerned if it is judged to be contrary to European Union law. It is stated by Article 263 of the TFEU which in its long wording rules different aspects; for the purposes we are here concerned with, the subjective and objective aspects have to be underlined as follows.

Firstly, an action for annulment may be brought against:

- All legal acts;

- Acts adopted by the Council, the Commission, the European Central Bank, the European Parliament and the European Council where these acts are intended to produce legal effects vis-à-vis third parties;

- Acts adopted by European bodies, offices or organisations where these acts are intended to produce legal effects vis-à-vis third parties;

- Measures adopted by the Board of Governors or the Board of Directors of the European Investment Bank ${ }^{24}$.

In addition, Article 263 excludes recommendations and opinions from the scope of the ECJ's jurisdiction.

Secondly, and from a subjective perspective, Article 263 distinguishes a few categories of plaintiff.

- Preferential plaintiffs: these are Member States, the Commission, the European Parliament and the Council. These plaintiffs are 'preferential' in the sense that they may bring an action for annulment before the CJEU without having to demonstrate any interest in taking action;

${ }^{24}$ Under the conditions of Article 271 of the Treaty on the Functioning of the EU. 
- Specific plaintiffs for specific actions:

... The Court of Auditors, the European Central Bank and the Committee of the Regions may bring actions against European acts which, in their view, undermine their prerogatives.

... The Board of Directors of the European Investment Bank may contest measures adopted by the Board of Governors of the Bank.;

... National parliaments and the Committee of the Regions may henceforth bring actions for annulment against acts which they consider to be contrary to the principle of subsidiarity ${ }^{25}$.

Finally, Individuals may also refer an action to the ECJ. They constitute the category of non-preferential plaintiffs and, in contrast to preferential plaintiffs; they must demonstrate an interest in taking action in order to request the annulment of a European act. According to Article 263, natural or legal persons may institute proceedings against ${ }^{26}$ :

- An act addressed to that person;

- A legislative or regulatory act of general application which is of direct and individual concern to them;

- Certain acts of general application, namely regulatory acts which are of direct concern to them and do not entail implementing measures ${ }^{27}$.

This general action to shape the legality of EU activity is initially understood from a non-formalistic perspective, considering that «an action for annulment must be available in the case of all measures adopted by the institutions, whatever their nature or form, which are intended to have legal effects» ${ }^{28}$.

25 Added by the Lisbon Treaty. It enabled as well individuals to challenge acts of bodies, offices and agencies once the Acts governing these bodies provide for such a possibility. Regarding this issue, it is interesting to follow the debate at the time of the European convention and the corresponding documents: See «Right of appeal against agencies created by secondary legislation» Working Documents 08 and 09 on Discussion Circle I — «Court of Justice»-), on the web page of the Secretariat of the European Convention (european-convention.eu.int). See also E. Nieto and I. Martin, European Administrative Law in the Constitutional Treaty, Hart Publishing 2007, p. 122 and ff

26 Order of the General court of 6 September 2011, Case T-18/10.

27 Added by the Lisbon Treaty; however, it was advanced in the CFI 3 May 2002, Case T-177/01, Jego-Quere; this judgment was later annulled by the ECJ (1 Apr 2004, Case C-263/02) considering the action could not be admitted due to the lack of (this) legal basis in the treaties. A recent interpretation on the concept of regulatory acts which do not entail implementing measures in ECJ Judgment 7 January 2013, Case T-96/10, Rütgers.

28 See the judgment in Case 22/70, Commission v. Council [1971]. 
However, this general statement does not correspond with the rigorous interpretation on when individuals comply with the conditions which are required for having access to the ECJ, which will be referred to bellow.

Regarding unlawful omissions by Community institutions, they can also be challenged before the ECJ by means of an «action for failure to act», which is governed by Article 265 TFEU $^{29}$. This action is open to natural and legal persons who, according to settled case law, may bring such proceedings aginst «a declaration that an institution has declined, in breach of the Treaty, to adopt decisions of which those persons are the potential addressees or which they could challenge in annulment proceedings» ${ }^{30}$. Formally, this action must be preceded by a formal notice calling on the defendant institution to act, specifying what decision should have been taken under EU law.

There is an interesting point related to this action, since it is connected with another procedural route, the action for infringement against Member States. As we will see, this action is only available for the Commission and Member States, not for individuals. If they consider that a member state should be brought before the ECJ, the only way for them is to address a petition to the Commission, which is not bound by it. That is, the Commission has discretion to decide whether or not to bring an action against a Member State after an individual has so petitioned, and its refusal to do so cannot be challenged by means of an action for failure to act. In this regard, «the Court has consistently held that natural and legal persons have no right ... to obtain a declaration that the Commission has failed to initiate a procedure for infringement of the Treaty» ${ }^{31}$.

b) Infringements by Member States.

The compliance of national activities with EU law is verified either at the EU or the national level, depending on the applicant. At the EU level, the ECJ has jurisdiction to take cognisance of an application brought by the Commission or by Member States against the alleged infringement attributed

29 «Should the European Parliament, the Council or the Commission, in infringement of this Treaty, fail to act, the Member States and the other institutions of the Community may bring an action before the Court of Justice to have the infringement established. ... Any natural or legal person may, under the conditions laid down in the preceding paragraphs, complain to the Court of Justice that an institution of the Community has failed to address to that person any act other than a recommendation or an opinion».

30 Order CFI 14 Jul 1994, Case T-13/94, paragraphs 13 and 14.

31 Order 30 January 2013, Case T-570/12, Estaser El Mareny, Order CFI 10 Jul 2001, Case T-191/00, Werner Edlinger v. Commission, paragraph 7. 
to a Member State (Articles 259 and 260 TFEU, action for failure to fulfil an obligation).

However, direct access to the ECJ to challenge national infringements is not granted to individuals: «No provision in the EEC Treaty provides for the possibility for a natural or legal person to bring before the Court an action directed against a Member State» ${ }^{32}$. If an individual looks for an infringement to be declared, he or she can complain before the Commission against the Member State, but finally it will be for the Commission to decide whether or not to bring an action before the ECJ. We have already pointed out that the Commission is not bound by the individual's petition to bring an action and that the refusal to do so cannot be the subject of an action for failure to act.

The usual way for individuals to claim against unlawful national implementation - normative or administrative- of EU law is an indirect one: to bring an action before the national courts. Within the framework of these national proceedings, the preliminary ruling will help the national judge to state the possible infringements. It is not for the ECJ to state whether or not there is an infringement of EU law, but simply to interpret the scope of the EU provision which is applied by the challenged national measure. However, the border line between the corresponding judicial functions is not always easy to perceive, as is clearly shown by the following opinion ${ }^{33}$ :

«From the very first references the Court has emphasised that its jurisdiction under Article 177 of the Treaty is limited to the interpretation of the rules of Community law, and that it has no jurisdiction with respect to the facts of cases... The facts (and the relevant rules of national law) must be established by the referring court, and it is that court which decides the case by applying, to the extent necessary, the interpretation which this Court has given to the relevant rules of Community law.»

\subsection{Indirect actions: preliminary references}

The preliminary ruling is a fundamental mechanism of European Union law aimed at enabling national courts to ensure uniform interpretation and application of EU law in all Member States ${ }^{34}$. Within the framework of national

32 Order ECJ 27 Sep 1991, Case C-285/90, Tsitouras.

33 See Opinion delivered on 10 July 1997 by Advocate General Mr Jacobs on Case C-338/95, paragraphs 12 and 13. Former Article 177 EEC Treaty is now the Article 267 TFEU.

34 See ECJ's «Information Note on references from national courts for a preliminary ruling», OJC 143, 11 Jun 2005. 
proceedings where EU Law is applied, a national judge could have difficulties regarding the interpretation of the European law, or may be uncertain as to the legality of acts of the European institutions. In those circumstances, the national judge may suspend the proceedings and make a reference for preliminary ruling asking the Court of Justice to interpret the European provision (interpretation) or to give a ruling on the validity of an act of the European institutions (validity). On the basis of the ECJ's answer, it will be for the national judge to restart the proceeding and to decide it.

When the individuals ask the national court for a preliminary ruling being referred to the ECJ, it is for the national judge to assess whether or not such preliminary ruling is necessary: Only the courts or tribunals against whose decisions there is no judicial remedy under national law, must, as a rule, refer the issue to the ECJ if the parties request it. However, this rule has some exceptions: «that obligation on national courts of last instance to make a reference for a preliminary ruling may be waived in exceptional circumstances in accordance with the conditions laid down in case-law, more specifically, when the question raised is the same as a question which has already been the subject of a reference for a preliminary ruling in an identical or similar case or, as the Court held in Cilfit , when the correct application of Community law is so obvious as to leave no scope for any reasonable doubt» ${ }^{35}$. According to some authoritative opinions, some high national courts have exceeded the rational use of this possibility, referring to these theories to avoid questions even when doubtless they needed to ask the ECJ ${ }^{36}$.

\section{PERSISTENT GAPS ON THE EU JUDICIAL REMEDIES FROM THE RIGHT OF A FAIR TRIAL PERSPECTIVE}

As the ECJ repeatedly states, «the Treaty has established a complete system of legal remedies and procedures designed to ensure judicial review of the legality of acts of the institutions and has entrusted such review to the Community Courts ${ }^{37}$. This system of legal remedies is settled on a two-fold outline, comprising direct actions before the ECJ and indirect actions laying down a cooperative working framework between national and EU judicial bodies.

35 See Conclusion of 12 April 2005, General Advocate Stix-Hackl in Case C-495/03, point 43, sumarizing previous case-law, particularly DaCosta case (1963) and CILFIT (1982).

36 See Opinion of General Advocate Ruiz Jarabo in Case C-461/03, particularly paragraphs 47 to 53. An attentive analysis in J. Morcillo, Teoría y Práctica de las Cuestiones Prejudiciales en el ámbito del Derecho Administrativo, La Ley Madrid 2010.

37 ECJ 25 Jul 2002, C-50/00 P, UPA, paragraph 40, and many earlier paragraphs. 
However, the word complete which qualifies the $E U$ system of remedies is more than controversial, at least in terms of efficiency, as such a system does not work well enough in all the situations where effective judicial protection is needed. The conditions allowing individuals to have access to the ECJ have been insistently considered om need of amendment, either by academic literature or by eminent legal practitioners heading European institutions and bodies during the process of drafting the European Constitutional text.

Neither the (intended) Constitution nor the Lisbon Treaties put an end to these situations: the present EU judicial system is affected by the Lisbon Treaty much more from a formal point of view than from a substantive one; the few amendments introduced by the Lisbon Treaty are still poor and insufficient, failing to increase in a significant way the judicial guarantees for individuals at the EU level or to provide a renewed, efficiently-working judicial system ${ }^{38}$.

These gaps could be detected in at least two aspects of the procedural regulations: on the one hand, the citizens' standing to sue, to directly bring an action before the ECJ, which is a much discussed issue among authors; on the other hand, the impact on (national) judicial independence of the organizational framework set up by EU Competition rules.

\subsection{Access to the ECJ for individuals. The preliminary reference as (alleged) compensation}

We have explained the ways provided by the EU Treaties for challenging the legality of EU law, which work directly before the ECJ and, indirectly, before the national courts examining a national measure which implements EU law. For direct actions — of annulment, for failure to fulfil obligations, for failure to act - citizens have very narrow access to the ECJ, if any. Addressing the national courts is the usual, albeit indirect, way to get judicial protection within the framework of a collaborative system, putting the two jurisdictional levels in touch by a «preliminary reference».

The access to the ECJ provided for individual, legal and natural persons is a highly controversial issue which has been repeatedly dealt with by the most authoritative opinions. In fact, the only direct access for individuals to the ECJ is set within the framework of the action of annulment by the fourth paragraph of

38 See RUIZ-JARABO COLOMER, «El Tribunal de Justicia de la Unión Europea en el Tratado de Lisboa» in Noticias de la Union Europea, No. 291, April 2009 p. 31 and ff. (Issue devoted to the Lisbon ). Relating the specific amendments the Lisbon Treaty made on this action, see above Footnotes 26 and 27. 
Article 263 TFEU, requiring of the applicant «direct and individual» affectation by the contested measures - which is hard to comply with in the case of measures having general effects. Furthermore, the ECJ understands «direct» and «individual» affectation in a very narrow way, laying down a word-to-word interpretation, and standing aside ${ }^{39}$ from other possible interpretations which would allow a wider and easier access to the ECJ as there was suggested by General Advocates.

The classic understanding on «direct and individual» affectation has not been changed by a possible influence of the Charter: in fact, the Explanations attached to the Charter clearly state that the right to an effective remedy before a court provided for by Article 47 «has not been intended to change the system of judicial review laid down by the Treaties, and particularly the rules relating to admissibility for direct actions before the Court of Justice of the European Union ${ }^{40}$. In fact, these classic criteria have been recently summarized and applied by the ECJ ${ }^{41}$ :

According to settled case-law, for an individual to be directly concerned by a European Union measure, first, that measure must directly affect the legal situation of that individual and, secondly, there must be no discretion left to the addressees of that measure who are responsible for its implementation, that implementation being purely automatic and resulting from European Union rules alone without the application of other intermediate rules...

It follows clearly from that case-law that two cumulative conditions must be satisfied in order for a measure to be capable of being regarded as being of direct concern to a natural or legal person...

[...]

in order for a contested act to be of individual concern to natural or legal persons other than the addressee of a decision, the act must affect those persons by reason of certain attributes peculiar to them or by reason of a factual situation which differentiates them from all other persons and distinguishes them individually in the same way as the addressee of a decision.

39 Arguing that it «cannot have the effect of setting aside the condition in question, expressly laid down in the Treaty», ECJ, 25 Jul 2002, Case C-50/00, paragraphs 44-45.

40 These Explanations, set up by a governmental body - the Praesidium of the Convention set up for the Constitutional Treaty - are referred to in the article 52, paragraph 7 of the Charter as a text which has to be taken into consideration for the interpretation of the Charter», as the recent ECJ judgment of 22 December 2010 (Case C-279/09), paragraph 32, reminds. There are available on http://www.europarl.europa.eu/charter/convent49_en.htm

41 See Order of the General Court of 6 September 2011, Case T-18/10, Inuit, paragraphs 71,72 and 88 respectively. 
Regarding access to the ECJ for associations, NGOs and similar legal persons, the Court applies these requirements cumulatively, leading to a restrictive result and a very different understanding of such entities from what is common at the national and EU levels. Generally,

an association formed to further the collective interests of a category of persons cannot be considered to be individually concerned ... by a measure affecting the general interest of that category ${ }^{42}$.

An action of annulment brought by these entities can be admitted under special circumstances, such as the role played by the association in a procedure which led to the adoption of the contested measures ${ }^{43}$.

From a broader scope, which considers the multiple legal sources currently interacting in the European space - in addition to the EU, the national laws and the European public order set up by the Council of Europe-, it can be concluded that the EU system holds the more restrictive view regarding the access to the courts provided for natural and legal persons and for collective entities $^{44}$. It is paradoxical if, furthermore, we consider as well the rigorous application the ECJ imposes on the conditions for access to the courts at the national level when EU law is involved, and particularly regarding the wider access the Aarhus Convention provides for environmental issues ${ }^{45}$.

Crucial in this debate is the opinion of General Advocate Mr Jacobs in the famous UPA case, highlighting, among many other interesting points, the lack of compatibility of the case law on locus standing with the principle of effective judicial protection in general, and in particular the serious delays and problems in the interim that lead to other disadvantages ${ }^{46}$. Similar analysis can be found on the preparatory works of the Constitutional Treaty, when some representa-

42 Order in Greenpeace and Others v. Commission, paragraph 59 upheld by the ECJ in its judgment in Greenpeace Council and Others v. Commission.

43 For example, when the applicant association was entitled both to negotiate and conclude a tax agreement with the Commission having effects for the represented sector (Order ECJ 3 May 1985, Cases 67 to 70/85, Van der Kooy and others v. Commission) or when the association plays a pre-eminent role in implementing the Commission's decision on state aid (Order ECJ 17 Jan 1990, Case 313/90, CIRFS and others v. Commission).

44 This view, considering the European legal system as the result of the (classic) European legal tradition (Council of Europe and National Law) and the (more recent) EU legal system, is developed in the collective work Judicial Review. A comparative analysis inside the European Legal System, S. Galera (ed.), Council of Europe publishing, 2010.

45 See C. REDGWELL, «Access to environmental justice» in Francioni, Access to justice, op. cit., particularly p. 166 and ff.

46 See his Opinion delivered on 21 Mar 2002, in toto. 
tives of the EU institutions aired coincidental opinions. In this regard, it is worth recalling the contribution of Judge Mr Vassilios Skouris, referring to «possible improvement in judicial protection» ${ }^{47}$, and rejecting the idea that the effect of increasing «the number of cases brought before the Court» could be considered a «criterion for determining whether to change these rules». In a similar vein, the final report of $\mathrm{Mr} \mathrm{A}$. Vitorino, Commissioner of Justice Issues, refers to the different proposals at the discussion circle on the Court of Justice ${ }^{48}$.

Although the Lisbon Treaty amended the action for annulment in order to enlarge the kind of decisions which can be challenged by individuals, it kept untouched the conditions on access for individuals. Consequently, the ECJ bases its persistent consideration of conditions of admissibility for individuals on a word-to-word interpretation of Article 263 TFEU, declaring that: «According to settled case-law, the Courts of the European Union may not, without exceeding their jurisdiction, interpret the conditions under which an individual may institute proceedings against a regulation in a way which has the effect of setting aside those conditions, expressly laid down in the Treaty, even in the light of the principle of effective judicial protection $»^{49}$.

It is argued that the narrow direct access for citizens to go before the ECJ is compensated with, and balanced by, the wider access citizens have to national courts for asking for a preliminary reference to be submitted to the ECJ (indirect access): it is said that if individuals do not comply with the demanding conditions of admissibility to bring an action before the ECJ, they can always initiate proceedings at the national level. In this way, and through the preliminary reference of the national court, citizens always have indirect access to the $\mathrm{ECJ}^{50}$.

However, a more detailed analysis of the content of the notion of «effective judicial remedy» emerging from this co-operative model between the two judicial levels suggests some objections. Firstly, the extend of the judicial review provided by the ECJ trough the action of annulment and the preliminary reference is not equivalent, as it is reflected on the ECJ reports themselves:

... judicial review in an action for annulment, both before the Court of Justice and before the Court of First Instance, of individual administrative

47 Currently, President of the ECJ: its hearing, «representing his own view, not the official position of the institution» can be found in Working Document 19, Working Group II, 11 Sep 2002, available at www.european-convention.int.

48 Working Document 08, Circle I, available at www.european-convention.int.

49 See ECJ Order of 6 September 2011 already cited, paragrph 51, with referentes to its previuos case-law (Case Jégo-Quéré 2004 and others).

50 This explanation was used early on by the ECJ in the well-known case Les Verts Case 294/83, Les Verts, paragraph 23. 
measures ... is more effective than that achieved by way of a reply to a reference for a preliminary ruling ${ }^{51}$.

... the approach taken by the Court of Justice (in preliminary reference) is purely legal. It is confined to the interpretation and assessment of the legality of legislative and individual acts of the Community institutions. Conversely, the procedural route of Article 230 (action of annulment) leads to the Community Court reviewing issues of substance such as the finding and assessment of facts ${ }^{52}$.

Secondly, the faculties of the parties to participate in procedural debate differ substantially in the two types of action. A national court is not bound to stay a preliminary reference proceeding each time the parties ask for it. This decision belongs to the national courts, not to the parties. Furthermore, the petitions, reasoning and observations made by the parties in an annulment procedure have a direct influence on the result; the observations presented in the preliminary reference procedure have a much more limited role.

Although the restricted access to the ECJ for citizens in annulment actions is probably the most criticised aspect of the EU judicial system, other serious limitations on access are identifiable. An action for failure to act is strictly reserved to privileged applicants: Member States and the Commission. Citizens can request the Commission to bring an action against a Member State, but the Commission has the discretion to decide whether to do $\mathrm{so}^{53}$. Its decision refusing to bring an action cannot be challenged by citizens either by an action of annulment or by an action for failure to act ${ }^{54}$.

Such a regulation sometimes leads to situations which are inconsistent with the general understanding of the right to a fair trial, with the ECHR appearing as the subsidiary way compensating the lack of access to the ECJ in particular cases. At this regard, the Dangeville case ${ }^{55}$ could be mentioned: a French company had been overtaxed on the basis of statutory provisions that were incompatible with a Community Directive, being its claims before the national courts successively dismissed. Yet there was no access for the taxpayer to the European courts in Luxembourg to challenge the incorrect national implementation, by way of an action for failure to satisfy a Community obligation. Thirteen years

51 Opinion of Mr Advocate General Cosmas, 16 May 2000, Case C-344/98, paragraph 55. Similar statements and criteria in Jacobs UPA.

52 Ibid., paragraph 52.

53 See the Opinion of the Advocate General Ruiz-Jarabo in case C-362/01.

54 See Order of the CFI 3 Jul 1997, Case T-201/96, among many others.

55 European Court of Human Rights, judgment of 16 Apr 2002, Dangeville v. France, confirmed in a similar case, Cabinet Diot and Grus Savoye v. France, European Court of Human Rights 22 Oct 2003. 
after the suit was initiated and only because the incorrect national implementation involved a fundamental right — the right to property — it was the Strasbourg Court that finally satisfied the applicant's claims, declaring that its right to peaceful enjoyment of its possession had been infringed. Would not the Luxembourg Court have been the natural jurisdiction to declare such infringements, avoiding thirteen years of legal disputes before the national courts? Was this delay consistent with the ECHR's doctrine on reasonable delay and the right to a fair trial?

It is questionable that the EU system of remedies complies in these cases with the Principle of effectiveness, which has been developed in a well-established ECJ case-law and insistently applied on the national system of legal remedies. There are no reasons for such principle not to be applied to the European system. According to it, «the detailed procedural rules governing actions for safeguarding an individual's rights under EU law must not make it in practice impossible or excessively difficult to exercise rights conferred by the EU law ${ }^{56}$. Thirteen years of judicial proceedings could perhaps be interpreted as an «excessively difficult» way to exercise rights provided by EU law.

\subsection{Judicial independence}

Judicial independence is a two-fold issue in EU law as it is applied either to the members of EU judicial bodies or to national ones. EU case-law has developed its own criteria on this concept, which have been shaped in great part when the ECJ has had to identify a national — non judicial body - as being able to present the preliminary reference as generally done by national judicial courts. It was in this context where «independence as an essential feature» has been underlined ${ }^{57}$.

Both the Treaties and the text governing procedures require «independence» as one of the main conditions that members of EU courts should fulfil. Article 254 TFEU establishes that «the Judges and Advocates-General of the Court of Justice should be chosen from persons whose independence is beyond doubt». The Statute of the Court of Justice imposes on the judges an «oath to perform their duties impartially» and confidentially, and establishes a specific

56 See Judgement on Case C-279/09 already cited, point 29.

57 The Spanish Tribunales Economico-Administrativos, though functionally dependent on the Finance Minister, has been recognised as a «judicial body» able to refer preliminary rulings to the ECJ (C-110/98 to C-147/98, Gabalfrisa judgment 2000, paragraphs 39 and 40). 
procedure to deprive a judge of office in the event he or she no longer fulfils the requisite condition or does not meet the obligations arising from the office ${ }^{58}$.

In EU case law, judicial independence has been recognised as part of the «right to a fair trial» and different faculties have been deduced from it depending on the varied situations to which it has been applied: In general terms, the ECJ, with specific reference to the Strasbourg Court's case law, states that:

- «the general principle of Community Law under which every person has a right to a fair trial, inspired by Article 6 of the ECHR, comprises the right to a tribunal that is independent of the executive power» ${ }^{59}$;

- the CFI, on the basis of Article 6 ECHR, declares that the «right of every person to a fair hearing by an independent tribunal means, inter alia, that both national and Community courts must be free to apply their own rules of procedure concerning the powers of the judge, the conduct of the proceedings in general and the confidentiality of the documents on the file in particular» ${ }^{60}$;

- «independence» is one of the required characteristics that determines whether a national body is a «court or a tribunal» empowered to refer a preliminary ruling to the ECJ: «the Court takes account of a number of factors, such as whether the body is established by law, whether it is permanent, whether its jurisdiction is compulsory, whether its procedure is inter partes, whether it applies rules of law and whether it is independent» ${ }^{61}$.

Consequently, a national regulation that omits sufficient safeguards for dismissal or termination of the members' appointment «does not appear to constitute an effective safeguard against undue intervention or pressure from the executive ${ }^{62}$ on the members of the national body.

We have already referred to the central role that EU Competition Law has assumed in the process of developing procedural guarantees which, finally, have been codified as individual rights by the Charter. This centrality is explained

58 Articles 2 and 6, respectively, relating to the judges of the ECJ, and Article 47 extending these requirements to the members of the CFI.

59 Case C-185/95 P Baustablgewebe 1998, paragraphs 20, 21; this criterion was repeated in ECJ 11 Jan 2000, C-174/98 P and C-189/98 P, paragraph 17 which pointed out some limits to this general statement.

60 See CFI resolution 19 Mar 1998, Case T-83/96, paragraph 47, and ECJ 11 Jan 2000 Gerard van der Wal, paragraph 14.

61 ECJ 31 May 2005, C-53/03, paragraph 29; I omit references to previous case law for easier reading.

62 Ibid., paragraph 31, citing Case 103/97, 1999, paragraph 21. 
on the basis of the Commission powers facing individuals in investigation procedures leading to verify their compliance with competition rules.

Council Regulation 1/2003 is the current legal framework regarding Competition Law: it abrogated the former one in force since 1962, reorganizing the procedures and the bodies trough which Competition Law is implemented. It pays special attention to the cooperation between the EU and the national level in order, it is said, to avoid harmful duplicities on individual rights ${ }^{63}$. It also reinforces the Commission's powers of investigation, which are balanced by additional procedural guarantees already appreciated by ECJ during precedent years. Among all of them, there are two specific provisions seriously interfering with the independence which has to be granted to the (national) judicial bodies $^{64}$.

a) National judicial functions limited by a Council Regulation?. The search warrants

The first controversial provision refers to the national search warrants that the national judicial bodies have to deliver at the Commission's request in the event that an undertaking company refuses to grant access to their buildings to Commission's officials. In these situations, the right to a «private home» granted either by Article 8 of the EConHR or by Article 7 of the EU Charter is involved ${ }^{65}$, and according to National Law a judicial search warrant should be issued.

For these purposes, the Regulation ${ }^{66}$ defines the task of national courts in providing this authorisation, and delimits their power, clearly establishing that the control be exercised by national courts is just a «control of the proportionality of the coercive measure», and adding that a «national judicial authority may not call into question the necessity for the inspection nor demand that it be provided with the information in the Commission's file». Similar provisions are estab-

63 General description of how this new system works could be found in Judgment of the Court of First Instance of 8 march 2007, Case T-339/04, France Telecom, points. 49 to 51.

64 A general description of functions of both jurisdictional levels on Cheynel, Benjamin: «Compétences respectives des juridictions nationale et communautaire dans le contrôle des inspections ordonnées par la Commission», Revue Lamy de la Concurrence : droit, économie, régulation $2007 \mathrm{n}^{\circ} 12$ p.85-86

65 I have already mentioned case-law about the extension for business companies to the right provided for articule 8 ECHR, adopted mainly in Hoestch (ECJ) and Niemeitz (ECHR) cases.

Article 20, paragraphs 7 y 8 . 
lished when private homes of directors, managers and other member of staff are involved in investigation proceedings (Article 21).

That means that Regulation 1/2003 limits, for national judges, the possibility of having all the information considered necessary before issuing the requested authorization, which comprises that included in the Commission's files. These limits has been confirmed by the $\mathrm{ECJ}^{67}$ in deciding on a preliminary rule submitted by the French Cassation Court ${ }^{68}$, although the ECJ has detailed the specific information ${ }^{69}$ that the Commission should provide to national courts when it asks them for a search warrant. In fact, there are two different resolutions provided by the Commission: firstly, the Decision which opens the inspection procedure -whose judicial scrutiny correspond to the European Courts - and, secondly, the Commission's application for assistance to the national judicial authority, which can be reviewed in accordance with the domestic remedies available, with the possible assistance of the Court of Justice trough the preliminary ruling.

In other words, national judges are neither able to request the whole information considered necessary to reach certitude regarding the necessity of the measure they are asked to adopt nor to demand that it be provided with the evidence in the Commission's file on which suspicions are based $»^{70}$. The necessity for an investigation, - that is to say, whether or not the arguments put forward by the Commission to justify it are convincing - is, each time it is disputed, subject to the review by the ECJ.

This is a controversial solution based on, once more, the "primacy of EU law and the need for its proper implementation», a reason that, in this context, does not convince everyone, at least not the General Advocate acting in the

67 Judgement of the Court of 22 October 2002, Case C-94/00, Roquette Frères. This criteria on limits for national judicial bodies has been later applied by the CFI, Judgment 8 of march 2007, case T-399/04, France Telecom.

68 Question put by French High Court litteraly were: «whether, having regard to the fundamental rights recognised ...the national court...cannot refuse to grant the authorisation requested where it considers that the information or evidence presented to it ... is not sufficient to authorise such a measure or where, as in the present case, no information or evidence has been put before it». This judgment applies the criteria previously stated in Hoescht and Niemeitz case-law.

69 «in particular, the grounds on which it suspects an infringement..., the gravity of the suspected infringement and the nature of the involvement of the undertaking concerned», See CFI Judgment 8 march 2007, Case T-340/04, France Telecom, paragraph 124.

70 See Judgment of the Court of 22 october 2002, case C-94/00. 
proceedings: certainly, he proposed that the right solution was for the search warrant to be provided by ECJ or $\mathrm{CFI}^{71}$, which was dismissed by the ECJ.

\section{b) Commission v. national courts criteria: Commission pre-eminence?}

A second group of questionable provisions in Regulation 1/2003 are the so-called «cooperation» provisions between the national and the EU level as far as they put further limits on national courts' functions. These provisions are applicable in the event that proceedings before national courts are coincidental with Commission proceedings regarding the same facts and legal - competition- rules. There are two different situations ${ }^{72}$ :

- First, the national courts are ruling on issues covered by competition European law «which are already subject of a Commission decision ${ }^{73}$ : in this event, they cannot take decisions running counter to the decision adopted by the Commission». That means that such decision, having administrative nature, is empowered by the Regulation with the "primacy effect» long ago recognized to EU Law by the ECJ, which implies that any divergent content of the national judgement is excluded from application;

- Second, national courts are about to rule while the Commission decision is not yet adopted in initiated and not finished proceedings: in this event, national courts «must also avoid giving decisions which would conflict with a decision completed by the Commission in proceedings it has initiated ... To that effect, the national court may assess whether it is necessary to stay its proceedings». That works as «preliminary ruling proceedings» between judicial and administrative bodies, giving preference to the latter.

This peculiar link between the Commission's decisions and the national judge has been admitted by the ECJ in its judgment on the Masterfood case (2000) and recently reconsidered in the light of Article 47 of the Charter within the framework of a preliminary reference ${ }^{74}$. The court confirmed its previous criteria, based on the «obligation of sincere cooperation between the

71 Opinion of Mr. Advocat General Mischo, case C-94/00, point.46; however, he added that as legislation does not provide this «right solution» dissociation of jurisdictional functions should prevail because of «consistency in the implementation of community law»

72 Article 16 Regulation $1 / 2003$.

73 This kind of «Decision» deciding competition law procedure have not regulative neither normative nature — the only community resolutions with «primacy effect»— but only are administrative acts.

74 Case C-199/11, Judgment of 6 november 2012, Otis et. Al. 
national courts, on the one hand, and the Commission and the EU Courts, on the other» required by the implementation of the EU competition rules (point 52). It reminded the exclusive jurisdiction of the ECJ to review the legality of the Commission's Decisions, concluding that such cooperation is a «specific expression of the division of powers, within the EU, between, on the one hand, national courts and, on the other, the Commission and the EU Courts» (point 54). However, in its answer, the ECJ omits any reference to the binding effects for the national court of the Commission decision although such consideration is stressed by the referring national court in its question ( $\ll \ldots$ as the national court seised of the matter cannot depart from the decision» of the Commission).

Once more, the «need for due implementation of EU Law» takes priority over any other consideration even when an essential feature of the Rule of Law is at stake. Contrary to other recent judgments where ECHR case-law has been deeply taken into consideration — due to Article 52 of the Charter ${ }^{75}$-, there are not any such references in this case. In fact, the ECHR's criteria on judicial independence hardly fits into this EJC pragmatic solution, as such criteria state that «the Court's independence from the parties and the executive means that, where it was dealing with a dispute that came within its jurisdiction, it could not have the solution dictated to it by one of the parties of by a representative of the executive» ${ }^{76}$.

\section{Final}

In general terms, the process of recognition of the right to a fair trial by EU Law has reinforced either the scope of the judicial review on the activity of the bodies creating and implementing EU Law or the powers of individuals while these public activities are performed. The Charter of Fundamental Rights gives recognition to these faculties long ago delimited and applied by the ECJ; furthermore, the Lisbon Treaty enlarged the scope of EU acts that can be challenged, among other amendments to the Articles providing for judicial remedies.

According to my view, a very valuable contribution of the Charter is the formal link with the Strasbourg Court's case-law which has to be considered in the interpretation of the rights provided for by it. In fact, ECJ case-law takes

75 See ECJ judgment of 22 December 2010, Case C-279/09, paragraph 32.

76 ECHR judgment of 13 February 2003, Chevrol v. France, paragraphs 64 and 80. A more detailed analysis on these criteria in my contribution to Judicial Review..., pages 165 and ff. 
into account the Strasbourg case-law more than ever: the ECHR's criteria on the right to a fair trial has been recently asserted either in cases where the Charter does not provide for a specific right which is granted by the European Convention (as the principle of culpability ${ }^{77}$ ) or in cases where the Charter adds judicial guarantees which have not been already applied at the EU level (legal aid for legal persons ${ }^{78}$ ).

Along with the lights, there are shadows in this process as well. First of all, as repeatedly pointed out by scholars, the access of individuals to the ECJ is still poor and insufficient, leading sometimes towards a procedural labyrinth involving two or three jurisdictional levels, which can hardly comply with the principle of effectiveness of the judicial system. In fact, as it has been wisely observed, the obligation to provide broad access to the courts has been addressed much more to national jurisdictions than it has been to the EU jurisdiction. This imbalance could be explained on the basis of the need for efficacy and due application of EU law. In the absence of a centralized administration applying EU law, its effectiveness depends to a large extent on national courts, requiring wide access for individuals to such courts in order to protect rights provided for by EU law, In these circumstances, «the right of access to justice receives implicit recognition inside the doctrine of 'direct effect' ... indeed, it is fair to describe direct effect as premised on a right of access to justices» ${ }^{79}$.

The same reason, the due implementation of EU law, explains a second set of provisions stated by the Competition legal framework which hardly comply with the elements the Rule of Law tradition requires for judicial bodies while performing jurisdictional functions. These elements are clearly defined by the ECHR whose criteria have been surprisingly ignored in recent judgments where the ECJ reconsidered this issue in the light of Charter provisions.

Possibly the remedies for such persistent gaps imply a deep revision of the EU judicial system itself, which is another not recent academic debate which reappeared during the works for the Constitutional Treaty. Even if this is not the right place to enter such a debate, I would like to remind an old proposal from the early nineties of the last century ${ }^{80}$ which nowadays acquires more value after the last EU enlargement: it entertain the idea of setting up Regional

77 Opinion General Advocate Mrs. Kokot, delivered on 28 February 2013, Case C-681/11.

78 Opinion General Advocate Mr. Mengozzi, delivered on 2 September 2010, Case C-279/09.

79 C. HARLOW, «Access to Justice», op. cit., p. 191.

80 JAQUÉ, J.P. and WEILER, J.H.H., «On the road to European Union. A new judicial architecture: an agenda for the intergovernmental conference», Common Market Law Review 1990, 27/02, pp. 185-207. 
Courts covering countries with similar legal traditions, working as decentralized European judicial bodies while the Luxembourg Courts remain as a last judicial resort.

Título:

EL DERECHO A UN JUICIO JUSTO EN EL DERECHO DE LA UNIÓN EUROPEA: LUCES Y SOMBRAS

\title{
Sumario:
}

1. El derecho a un juicio justo garantizado por el artículo 47 de la Carta. 2. Evolución previa: desde los principios a los derechos individuales y a la Carta. 3. Los recursos en la UE. 3.1 Acciones directas. a) Infracciones por las instituciones y autoridades europeas; b) Infracciones por los Estados miembros. 3.2 Acciones indirectas: referencias preliminares. 4. Persistentes lagunas en los recursos judiciales de la UE desde la perspectiva del derecho a un juicio justo. 4.1 Acceso al TJUE para los individuos. La referencia preliminar como (supuesta) compensación. 4.2 Independencia judicial. a) ¿funciones judiciales nacionales limitadas por un Reglamento del Consejo? El allanamiento. b) ¿Comisión vs. Criterios de los tribunales nacionales: primacía de la Comisión? 5. Conclusiones.

\begin{abstract}
:
This Article is focused on one of the rights provided for by Article 47 of the Charter, the right to a fair trial. It is not a new contribution of the Charter but a guarantee which has been provided by EU Law for decades. It first appeared as a procedural right, was later recognized as a general principle of the EU and was finally embodied in the Charter. Consequently this work recalls that process of recognition, paying special attention to the judicial remedies provided by EU law and to some specific rules of secondary - competition - law which affect the context on which the right to a fair trial is developed. The article concludes by underlining, on the one hand, the improvements on the right to a fair trial brought about by this legal process and, on the other hand, a few gaps on the issue which are neither recent nor consistent with the effectiveness and completeness of such right as it is required by the Rule of Law tradition.
\end{abstract}

\section{Resumen:}

Este artículo se centra en uno de los derechos previstos por el artículo 47 de la Carta Europea de Derechos, el derecho a un juicio justo. No es 
una nueva aportación de la Carta, pues se trata de una garantía de que ha sido proporcionada por la legislación de la UE durante décadas. Primero apareció como un derecho procesal, más tarde fue reconocido como un principio general de la Unión Europea y finalmente fue incorporado a la Carta. Por lo tanto, este trabajo recuerda ese proceso de reconocimiento, prestando especial atención a los recursos judiciales de derecho de la UE y a algunas normas específicas de derecho derivado que afectan al contexto en que se desarrolla el derecho a un juicio justo. El artículo concluye subrayando, por un lado, las mejoras sobre el derecho a un juicio justo provocado por este proceso legal y, por otra parte, algunas lagunas en este ámbito que son ni recientes ni compatibles con la eficacia y la integridad de ese derecho, como lo exige la tradición del Estado de Derecho.

\section{Key words:}

right to a fair trial; access to the courts; judicial remedies; judicial independence.

\section{Palabras clave:}

derecho a un juicio justo; acceso a los tribunales; recursos judiciales; independencia judicial. 